\title{
International Symposium "Man in the sea - in situ studies on life in oceans and coastal waters": Opening address
}

\author{
O. KINNE \\ Biologische Anstalt Helgoland (Zentrale); \\ Hamburg 50, Federal Republic of Germany
}

Ladies and gentlemen!

Dear colleagues and friends!

Herzlich willkommen auf Helgoland! A most cordial wetcome to Helgoland this stubborn big rock of red sandstone, which has held out against erosive wind, ice and water for some 20 million years (and, hopefully, will continue to do so for the next 20 million years). I welcome you most cordially also to the Biologische Anstalt Helgoland, which was founded on this big rock 80 years ago. We appreciate that 161 colleagues from 20 countries have come here to attend the International Helgoland Symposium, 1972, devoted to the topic: "Man in the sea - in situ studies on life in oceans and coastal waters".

Man in the sea! What about woman? How about equal opportunities for both sexes? On land and underwater? I am sorry to note very few ladies. Could the title have kept others away? I hope not. Of course, women are needed! They are needed for underwater research and ... how else could we dance tonight in the Kurhaus?

Today, we begin the 5th International Symposium sponsored by the Biologische Anstalt Helgoland. The first two Symposia, in 1963 and 1965, were concerned with "Quantitative biology of metabolism"; the third, in 1967, with "Biological and hydrographical problems of water pollution in the North Sea and adjacent waters". The fourth was held in 1969 and devoted to the topic "Cultivation of marine organisms and its importance for marine biology". All respective proceedings have been published in our journal "Helgoländer wissenschafliche Meeresuntersuchungen".

Financially, this Symposium is supported by the Minister of Education and Science of the Federal Republic of Germany. I am grateful for this support and happy to convey to you the Minister's best wishes for a fruitful and successful meeting.

In situ studies on life in the marine environment have added a new dimension to the field of marine biology. In the past, marine biologists have either recorded or 
sampled from aboard ship, or they have exposed their organisms to controlled but artificial environments in the laboratory. Both methods have yielded rewarding results; but both (as any method) have their shortcomings: recording and sampling at sea yield information which makes it difficult to relate cause and effect; analyses under laboratory conditions may defy extrapolation of the results obtained to field conditions.

In situ observations and in-situ experiments can help to lessen the gap between ship data and laboratory analyses and to open up new vistas beyond our present horizon. They elucidate ecological and behavioural aspects which cannot be examined by collecting techniques nor by experiments under conventional laboratory conditions. They allow critical re-assessments of sampling and recording techniques. They facilitate studies on fisheries, and ad hoc assessments of water pollution. There can be no doubt: Man-in-the-sea techniques provide important methodological prerequisites for investigating life in oceans and coastal waters.

Three main categories of man-in-the-sea techniques are presently available: (1) SCUBA, the self-contained underwater breathing apparatus; (2) underwater laboratories (UWLs), providing a habitat for long-term observations and experiments under conditions of saturation diving; (3) submersibles, with non-pressurized or pressurized respiratory gases, which serve as mobile vessels for scientific underwater missions. In addition, a large variety of unmanned devices is now at hand, challenging the need of manned missions, and adding arguments to a controversy similar to that known from space programmes. The pros and cons of manned versus unmanned missions into the hazardous environments of sea and space are largely a matter of perspective and aim. We shall attempt to contribute to this discussion, from the viewpoint of the marine biologist, during the two Informal Sessions of this Symposium, to be convened by Drs D. C. Beaumariage and J. B. Bunt.

The technique of SCUBA diving was pioneered in France by JACQUES-Yves CoUStEAu and EMILE GAGNAN in the 1940's, and introduced to marine biology by the Austrian HANS HAss. In the 1950's, a few renowned institutions began to make use of SCUBA diving in their research programmes; for example, the Marine Laboratory at Aberdeen (Scotland), the Murmansk Marine Institution (USSR), the Fisheries Laboratory at Lowestoft (England), the Scripps Institution of Oceanography (USA) and the US Bureau of Commercial Fisheries. However, initial progress was slow. The experimental marine biologist was too deeply involved in his laboratory work; and his sea-going counterpart, the biological oceanographer, relied exclusively on recording and collecting from aboard ship. In addition, the emphasis placed on sport and sensationalism during early SCUBA-diving events created an atmosphere which did not promote acceptance of the new techniques by more formal-minded scientists. The vacillating, hesitating slowness encountered by the first phase of the man-in-the-sea-movement has now turned into enthusiasm and success. In the last 10 years, SCUBA diving has become indispensable for ecological and behavioural in-situ work.

Underwater laboratories have greatly augmented man's capability to work and experiment in the sea. Employing the concept of saturation diving and using the UWL as habitat, SCUBA divers advance to the status of aquanaut. The aquanaut makes the sea his temporary home. He has more diving time available per 
day than the surface-pressure dependent SCUBA diver; he is no longer a transient visitor but a resident of the underwater community studied; as observer and experimenter, he attains a state of total immersion and participation never experienced before. The new effect of total immersion is enhanced when closed-circuit rebreather units are used. In contrast to conventional SCUBA equipment, these units do not disturb the local scene by producing the foreign noise and sight of the streams of air bubbles. Aquanauts operating from an underwater habitat and wearing a closedcircuit rebreather system are men-in-the-sea in the most literal sense of that term and at the highest level of technical perfection yet attained. They remain in the sea until their task is completed. They then need to undergo only a single sequence of decompressions, re-adjusting their gas-saturated tissues to surface-pressure conditions. Effective long-term saturation diving requires a reasonably comfortable habitat to retire to for replenishment of resources, for resting, as well as for preparing, conducting and evaluating the observations and experiments performed in the sea.

In 1962, the first proof that man can live and work underwater for extended periods was provided by E. A. LiNk's man-in-the-sea programme (USA), during which a diver spent 24 hours at $61 \mathrm{~m}$ depth in the European Mediterranean Sea near Villefranche using a submersed decompression chamber as primitive habitat. Almost at the same time, J.-Y. Cousteau launched the Precontinent I-habitat near Marseille in a mission during which 2 divers lived 1 week at a depth of $10 \mathrm{~m}$ (PARrish 1972). A series of about 60 underwater laboratories, built and tested by scientists and engineers from some 20 different countries, has followed these pioneering efforts until this day. The most well-known underwater laboratories remain Precontinent, Sealab, Sadko, Ichthiander, Tektite, Chernomor (Borovmov \& YASTrebov 1969) and Aegir.

The contributions made by the Federal Republic of Germany and by this institution - the "Biologische Anstalt Helgoland" - are modest. The first underwater laboratory built in Germany was BAH I. In 1968, this simple $2 \times 6 \mathrm{~m}$ habitat was successfully tested, under my direction, during an 11-day, 2-man mission at $11 \mathrm{~m}$ depth in the Baltic Sea. In 1969, the "Biologische Anstalt Helgoland" (BAH) and the "Institut für Flugmedizin" (IfF) planned and completed successfully the first underwaterlaboratory mission under the rough weather and water conditions prevailing in the North Sea, one of the most dangerous seas on this globe. The UWL "Helgoland" mission lasted from July 28 to August 19 and was directed by Professors $\mathrm{O}$. KINNE (BAH) and S. RUFF (IfF).

The stable, technically well-equipped $2.5 \times 9 \mathrm{~m}$ habitat was lowered to a depth of $23 \mathrm{~m}$, about $2 \mathrm{~km}$ east of the "Dïne", near Helgoland; for 21 days, it provided a safe base for 3 teams of aquanauts. It was possible to complete a number of observations and experiments in the turbid and cold waters, and the aquanauts returned to the surface, convinced that worthwhile underwater research can be performed, even under the unfavourable conditions found on our doorstep. Following the 3-week manned mission, UWL "Helgoland" remained in the sea unmanned for 9 months. It emerged from storm-beaten waters overgrown by a large variety of organisms, corroded at various external parts, but otherwise in good shape. Details on technical and scientific aspects of this first UWL-programme in the southern North Sea have been published in a number of papers (e.g. Brologische Anstalt Helgoland 1969, 1970, 1971, 1972 , 
Kinne \& Ruff 1969, Fust \& Oser 1970, Haux 1970, Kinne 1970a, b, c, Ruff 1970 , von HeNtig 1971, KRUmbein 1971, Luther 1972, Uhlig 1973).

The third main category of man-in-the-sea techniques, the submersibles, comprises bathyscaphs, tethered submersibles, self-propelled free submersibles, and diver-lock-outs. WiLLIAM BEEBE's descent to a depth of nearly $1000 \mathrm{~m}$ within a steel sphere, lowered from a ship in the early 1930's, stimulated construction and testing of a large number of submersibles, representing a surprising variety of technical concepts. It must suffice here to mention, of a total of about 150, FNRS, Trieste, Atlant-1, Guppy, Hydrostat, Kuroshio, Severyanka, Ben Franklin, Deep Quest, Aluminaut, Alvin, Johnson-Sea Link, Deep Star, Diving Saucer, Stars, and Pisces.

To which fields of marine biology can SCUBA diving, underwater laboratories, and submersibles contribute most?

First of all, they can contribute substantially to the study of ecology and behaviour under in-situ conditions. We know little as yet about functional and structural dynamics of ecological systems in the unrestrained marine environment. And we know just as little about normal behaviour related to feeding, reproduction, aggregation, migration, schooling, territorialism, habitat selection, orientation, communication, and timing under natural conditions.

Secondly, man-in-the-sea programmes can contribute to making available living and non-living resources. And they can help to develop and to apply better devices for quantitative or protective collection of micro-organisms, algae, plankton, molluscs, crustaceans, fishes, etc., than are presently available.

Thirdly, they can contribute to protecting living resources from dangerous activities of modern man, such as water pollution and over-exploitation. We all know that reliable assessment of water pollution is difficult on the basis of laboratory experiments alone. In-the-sea studies may help to provide a more adequate fundament for successful environmental protection and for management of living resources.

Finally, SCUBA, underwater laboratories and submersibles can help to improve the systems which measure and record levels and fluctuation patterns of environmental factors determining abiotic and biotic characteristics of a given marine habitat. Smallscale differences, involving significant environmental changes in neighbouring microhabitats (e.g. on or in certain substrates), can be located and determined more directly and more precisely by man in the sea than by man on a ship.

What do we expect of this Symposium? The meeting has been organized in order to bring together marine scientists - representing different disciplines and different countries - concerned with in situ studies in the marine environment. It is my sincere wish that important recent results obtained in the field of biological underwater research will be presented and discussed here in an atmosphere of openess and fairness and that the meeting will contribute significantly to

(1) assessing the usefulness of in situ technologies for solving marine biological problems;

(2) conveying an objective picture of the state of the art;

(3) pointing out important new problems to be solved in the near future. 
Recently, a Working Party - established on the recommendation of the FAO Advisory Committee on Marine Resources Research (ACMRR) - has reviewed the existing know-how on the use of underwater habitats and submersibles in fisheries and marine biology (PARrish 1972). The group concluded that, while a full evaluation is not yet possible, "it seems abundantly clear that 'man in the sea' techniques have an important role to play in a wide range of both basic and applied research problems". ... "It is important to recognise that submersibles and underwater habitats are not ends in themselves, as some critics infer, but research tools the usefulness of which for any investigation must be subject to the same objective assessment as other tools" (p. 163). We share these views.

How about the less scientific - the more leisurely, human aspects of this symposium? Well, we hope that the weather will continue to be with us, and that the dancing tonight, the swimming pool exercise on Tuesday, and the Dünenparty on Thursday evening will help to lessen the burden of the mental involvement during paper presentations and discussions. There are further opportunities for physical exercise. There is fishing, tennis, and sauna. And there are the stairs to the "Oberland". A total of 181 stairs. If you climb these stairs 296 times, you will have made Mt. Everest!

For the next 5 days, I wish all of you a balanced measure of work and leisure, and rewarding, pleasant days on Helgoland. I hereby open the International Helgoland Symposium 1972: "Man in the sea - in situ studies on life in oceans and coastal waters".

\section{LITERATURE CITED}

BroLogrsche Anstalt Helgoland, 1969. Jahresbericht 1968, Ca $1-84$.

- 1970. Jahresbericht 1969, Ca $1-81$.

- 1971. Jahresbericht 1970, Ca 1-86.

- 1972. Jahresbericht 1971, 1-94.

Borovikov, P. A. \& YASTREBov, V. S., 1969. The "Chernomor" programme. Underwat. Ass. Rep. 4, 32-34.

Fust, H.-D. \& Oser, H., 1970. Die technischen und medizinischen Erkenntnisse aus dem Einsatz des „UWL Helgoland“. Meerestechnik 1, 17-23.

Haux, G., 1970. Tauchtechnik, Springer, Berlin, 2, 1-288.

Hentig, R. von, 1971. Wissenschaftler auf Tauchstation. Bild Wiss. 1971, 1116-1123.

KInNe, O., 1970a. Erste Erfahrungen mit dem Unterwasserlaboratorium „Helgoland“ (UWL-H). (Zweiter Teil.) Systems 69. (Internationales Symposium über Zukunftsfragen) Dt. Verl. Anst., Stuttgart, 293-301.

- 1970b. Unterwasserlaboratorium "Helgoland“. Ein naturwissenschaflich-technisches Pionierunternehmen. Naturwissenschaften 57, 480-487.

- 1970c. Unterwasserforschung mit dem UWL-H. Umschau 10, 304-307.

- \& Rurf, S., 1969. Unterwasserlaboratorium „Helgoland". Bild Wiss. 1969, 1176-1183.

Krumbern, W. E., 1971. Sediment microbiology and grain-size distribution, as related to tidal movement, during the first mission of the West German Underwater Laboratory "Helgoland". Mar. Biol. 10, 101-112.

LUTHER, G., 1973. UWL "Helgoland" - an underwater laboratory for rough sea conditions. Helgoländer wiss. Meeresunters. 24, 45-53. 
PARRISH, B. B., 1972. Submersibles and underwater habitats: a review. Underwat. J. Inf. Bull. 4, $149-167$.

RuFF, S., 1970. Erste Erfahrungen mit dem Unterwasserlaboratorium „Helgoland“ (Erster Teil). Systems 69. (Internationales Symposium über Zukunftsfragen.) Dt. Verl. Anst., Stuttgart 286-292.

UHLIG, G., 1973. Assessment of Underwater Laboratory "Helgoland's" mission in 1969. Proc. Soc. Underwat. Tech. (in press).

Author's address: Prof. Dr. O. KINNE

Biologische Anstalt Helgoland (Zentrale)

2 Hamburg 50

Palmaille 9

Federal Republic of Germany 